\title{
An Analysis of Judges' Considerations in Making Decision About the Case of Application for Marriage Dispensation After the Enactment of Law Number 16 of 2019 Concerning Marriage
}

\author{
Jamaluddin $\mathbf{T}^{1}$ \\ Lecturer at the State Islamic Institute Bone \\ E-mail:azyadjamal8@gmail.com
}

\section{Yusuf Djabbar ${ }^{2}$}

Lecturer at the State Islamic Institute Bone

E-mail:djabbaryusuf@gmail.com

\section{Abstract}

After the enactment of Law no. 16 of 2019 concerning marriage which substantially regulates the age of marriage. The increase in the age of marriage regulated in the law has become a polemic in the community, so to obtain their rights, a marriage dispensation is proposed. The application for Marriage Dispensation has become a polemic, because the community has not been able to adapt, so with many reasons the judge can grant the request.Therefore, it is urgent to reveal the judge's considerations as a result of the judge's decision on marriage dispensation. This research is a qualitative field research in the field of law. The research location focuses on the study of judges' considerations in applying for a marriage dispensation at Watampone Religious Court.The approach used in this research is a normative juridical approach, an empirical juridical approach and a sociological juridical approach. The analysis used is descriptive qualitative, with the aim of collecting data, described or described in the form of sentence exposure in accordance with the formulation of the problem. The research findings show that judges in examining and adjudicating marriage dispensation cases are carried out based on the Republic of Indonesia Supreme Court Regulation Number 5 of 2019 concerning Guidelines for Adjudicating Applications for Marriage Dispensation. The judge's consideration in making decisionof application for a marriage dispensation emphasizes a persuasive approach and considers the benefit. The implication of this finding is that in the case of dispensation, it should be considered carefully, for the sake of the continuity of the marriage relationship.

Pasca berlakunya UU No. 16 Tahun 2019 tentang perkawinan yang secara subtansi mengatur perihal usia nikah. Peningkatan usia nikah yang diatur dalam UU telah menjadi polemik di tangah masyarakat, maka untuk 
mendapatkan hak-haknya diajukan dispensasi kawin. Permohonan dispensasi kawin menjadi polemik, karena masyarakat belum bisa beradaptasi, sehingga dengan banyak alasan untuk dapat dikabulkan permohonannya oleh hakim. Maka urgen untuk mengungkap pertimbangan-pertimbangan hakim hasil putusan hakim tentang dispensasi kawin. Penelitian ini merupakan penelitian lapangan (field research) yang bersifat kualitatif di bidang hukum. Lokasi penelitian terfokus pada kajian pertimbangan hakim dalam pemohon dispensasi kawin di Pengadilan Agama Kelas 1 A Watampone. Pendekatan yang digunakan dalam penelitian ini adalah pendekatan yuridis normatif, pendekatan yuridis empiris dan pendekatan yuridis sosiologis. Analisis yang digunakan adalah deskriptif kualitatif, dengan tujuan mengumpulkan datadata, diuraikan atau dijabarkan dalam bentuk pemaparan kalimat sesuai dengan rumusan masalah. Hasil temuan penelitian menunjukkan bahwa hakim dalam memeriksa dan mengadili perkara dispensasi kawin dilaksanakan berdasarkan Peraturan Mahkamah Agung RI Nomor 5 Tahun 2019 tentang Pedoman Mengadili Permohonan Dispensasi Kawin. Pertimbangan hakim dalam memutuskan permohonan dispensasi kawin menekankan pendekatan persuasif dan mempertimbangkan kemaslahatan. Implikasi temuan ini bahwa sebaiknya dalam kasus dispensasi dipertimbangkan dengan matang, demi keberlangsungan hubungan perkawinan.

Key words: Judge's consideration; case decision making; marriage dispensation.

\section{Introduction}

Marriage is human nature (fitrah), thus that it is orderly and does not cause chaos and disease, representative regulations are needed. The fitrah given by God is to fulfill biological needs and inner peace in which there is love and affection and to obtain legitimate offspring according to Islamic law. In Islamic marriage law, it is known that there are pillars and conditions of marriage. Pillars include: prospective husband, prospective wife, marriage guardian, two witnesses, and the solemnization of a marriage. The requirements include, the prospective husband or wife is to reach the minimum age limit. In Article 7 paragraph 1 of Law no. 16 of 2019 concerning amendments to Law no. 1 of 1974 concerning marriage, marriage is only permitted if a man and a woman have reached the age of 19 (nineteen) years, because marriage is a juridical agreement. ${ }^{2}$ The revision of the Marriage Law aims to suppress the increase in the marriage of minors. ${ }^{3}$

${ }^{1}$ See QS. Al-Rūm/30: 21.

${ }^{2}$ Rusli, Nur Mohamad Kasim, and Duke Arie Widagdo. "Law Enforcement on the Inheritance of Siri Married in the Judicial Verdict." Al-Bayyinah 4.2 (2020): 133-150.

${ }^{3}$ Mughniatul, Ilma, "Regulasi Dispensasi dalam Penguatan Aturan Batas Usia Kawin bagi Anak Pasca Lahirnya UU No. 16 Tahun 2019." AL-MANHAJ: Jurnal Hukum dan Pranata Sosial Islam 2.2 (2020): 135 
However, social reality shows that there have been a lot of marriages whose age has not reached the minimum age as determined by law, both prospective husbands and prospective wives. Director of Population Impact Analysis, National Population and Family Planning Agency (BKKBN) HitimaWardhani revealed that there are 375 teenagers getting married at an early age everyday. ${ }^{4}$ After the enactment of Law no. 16 of 2019 concerning Marriage, cases of marriage dispensation have increased, from Watampone Religious Court data received in 2016 there were 127 cases, in 2017 there were 154 cases and 145 cases were granted, in 2018184 cases were granted and 142 cases were granted,while those received in 2019 were 227 cases and 210 cases were granted. ${ }^{5}$

Table. 1.1.

Number of Cases of Application for Marriage Dispensation for 2017-2019

\begin{tabular}{cccc}
\hline No. & Year & Received & Granted \\
\hline 1. & 2017 & 154 & 145 \\
\hline 2. & 2018 & 184 & 142 \\
\hline 3. & 2019 & 227 & 210 \\
\hline & Jumlah 3 tahunterakhir & 556 & 497 \\
\hline
\end{tabular}

The fact above shows that in the last three years, cases of underage marriage in Bone Regency are in the high category and are increasing every year. This condition has triggered the emergence of slanted statements and perceptions from the public on the performance of Watampone Religious Court.The community considers Watampone Religious Court to make it easier for underage marriages to occur, their reason is because Watampone Religious Court is very easy to give a decision or determination that allows minors to get married, in the sense that it is very easy to grant a case for a Marriage Dispensation that is submitted to the Supreme Court. ${ }^{6}$

In connection with the increase in the number of cases of marriage dispensation after the enactment of Law no. 16 of 2019 at Watampone Religious Court, it becomes interesting to study in various aspects. In addition to realizing the legal objectives, namely justice, certainty and expediency, it is urgent to analyze the

${ }^{4}$ Republika, BKKBN: 375 Remaja Menikah Dini Setiap Harinya, Lihat https://nasional.republika.co.id/berita/nasional/umum/ps4am9459/bkkbn, Accessed on, Wednesday, 7 August 2019.

${ }^{5}$ Watampone Religious Court Annual Report Data in 2018.

${ }^{6}$ Ahmad Amiruddin, Watampone Religious Court Administrative Official, Interview on Jalan Laksamana YosSudarso, 23 July 2019. 
determination of the judge's decision in determining the marriage dispensation. The basis for consideration of the judges of Watampone Religious Court in casukonstatir (legal analysis) in determining the Marriage Dispensation for minors. Legal analysis of judges in examining and adjudicating child marriage dispensation cases and the causes of filing cases of minor marriage dispensation applications. This is to get a strong analysis of a judge grating or rejecting a marriage dispensation application.

\section{Methodology}

This research is a qualitative field research in the field of law, by explaining the judge's legal considerations in determining the case of a marriage dispensation application at Watampone Religious Court. The location of the research focuses on the study of judges' considerations in applicants for marriage dispensation at Watampone Religious Court.

The research approach is a paradigm or perspective contained in a field of science which is then used in understanding the problem. ${ }^{7}$ The approaches used in this research include:First, the normative juridical approach, namely analyzing data by using an approach through arguments or rules that guide human behavior. ${ }^{8}$ Normative legal research is legal research conducted by examining library materials or secondary data. ${ }^{9}$ Second, the empirical juridical approach is the facts or phenomena in the form of implementing regulations relating to marriage dispensation. Third, the sociological juridical approach is a research based on a legal provision and social phenomena or events that occur in the field.$^{10}$ The analysis used to collect data, is described or described in the form of sentence exposure in accordance with the formulation of the problem. Focuses attention on certain aspects and often shows the relationship between variables. ${ }^{11}$ In this way, the reasons for the application for a marriage dispensation and the judge's analysis in making decision will be illustrated.

\footnotetext{
${ }^{7}$ Abuddin Nata, Metodologi Studi Islam (Jakarta: Raja Grafindo Persada,1998), p. 98.

${ }^{8}$ Soerjono Soekanto, Pengantar Penelitian Hukum (Third Print, Jakarta : UI Press, 1986), p. 10.

${ }^{9}$ Soerjono Soekanto, and Sri Mamuji, Penelitian HukumNormatif (First Print, Jakarta: PT Raja Grafindo Persada, 1990), p. 13.

${ }^{10}$ Soerjono Soekanto, Penelitian Hukum Normatif: Suatu Tinjauan Singkat (Jakarta: Raja Grafindo, 2001), p.26.

${ }^{11}$ S. Nasution, Metode Research (Penelitian Ilmiah), p. 24.
} 


\section{Discussion}

\section{Legal Considerations of Judges in Making Decision corcerning Marriage Dispensation}

Underage marriage is permitted by issuing a marriage dispensation to the court as long as the religion is relevant. ${ }^{12}$ The case for the application for a marriage dispensation according to the Supreme Court Regulation (PERMA) Number 5 of 2019 is different from the general case as mentioned above because the judge who hears the marriage dispensation case is the sole judgeso that in the trial stage there is no longer deliberations of the assembly, but only with the analysis and decision of the judge. ${ }^{13}$ Judgment is a term given to the product of the results of the trial of contentious cases (cases containing disputes), this type of case is also called a lawsuit. Stipulation is a term given to the product of the results of the trial of voluntary cases (cases that do not contain disputes). Therefore, the case for a marriage dispensation is included in the group of voluntary cases or cases that do not contain disputes. Marriagedispensation is part of the marriage, which is the authority of the religious court, to be proposed and obtain a decision.

Based on the results of research by researchers on 17 decisions of Watampone Religious Court in the form of stipulations on the Marriage Dispensation, namely cases number 159, 161, 162, 166, 168, 169, 171, 177, 180, 181, 192, 198, 199, 201, 203, 204, and 206/Pdt.P/2020/PA.Wtp, show that in general the legal basis for the judges' legal considerations in the case of a marriage dispensation application refers to PERMA Number 5 of 2019 concerning Guidelines for Adjudicating Applications for Marriage Dispensation.The Deputy Chairperson of Watampone Religious Court confirmed that the judge in examining and adjudicating the case for a marriage dispensation application refers to civil procedural law in general and in particular to PERMA Number 5 of 2019 concerning Guidelines for Adjudicating an Application for a Marriage Dispensation where the nine items mentioned above are the main considerations in giving a decision ${ }^{14}$

The series of judges' decision making in the case of marriage dispensation will be described below;

${ }^{12}$ RachmadiUsman, Aspek-Aspek Hukum Perorangandan Keluarga di Indonesia (Jakarta: Sinar Grafika, 2006), p. 275.

${ }^{13}$ Republic of Indonesia, Supreme Court Regulation Number 5 of 2019 concerning Guidelines for Adjudicating Applications for Marriage Dispensation, Chapter I, Article 1 paragraph 11.

${ }^{14}$ Saifuddin, Deputy Chairperson of Watampone Religious Court, Online Interview Via Whatsapp, 18 June 2020. 


\section{1) Peace efforts/judge advice}

Article 12 paragraphs (1) and (2) of PERMA Number 5 of 2019 above indicate that the application for Marriage Marriage Dispensation of minors has made efforts to raise awareness of the dangers posed by underage marriage. If the amicable effort or the judge's advice is successful, the trial is not continued or stopped and the case is declared revoked, but if the amicable effort or the judge's advice is unsuccessful, it is because the situation and condition of the two prospective husbands/wives are very intimateor there are even those who are pregnant and their readiness, both the bride and groom and both families are ready and supportive, then the trial process will continue according to the instructions of PERMA Number 5 of 2019 concerning Guidelines for Adjudicating Applications for Marriage Dispensation.

2) Absolute Competence on Marriage Dispensation Cases

As for point 2, it shows that the case for the application for Marriage Dispensation for applicants who are Muslim is the absolute authority of the Religious Courts in examining and adjudicating them. Based on Article 2 of Law No. 3 of 2006 concerning Amendments to Law No. 7 of 1989 concerning Religious Courts which reads that "Religious Courts are one of the actors of judicial power for people who seek justice who are Muslim regarding certain cases as referred to in Law".This shows that the Religious Courts adhere to the principle of "Islamic Personality" meaning that only Islamic civil cases are tried in the Religious Courts.

Thus, in general, all regencies throughout Indonesia are dominant/majority of Islam, so that with this competence coupled with the dominance of the Muslim population, the Religious Courts throughout Indonesia, including in Bone Regency, increase the number of cases in the voluntary field.

3) Listening to the Opinions of the Bride and Groom

Based on Article 14 paragraph (1) of PERMA Number 5 of 2019 concerning Guidelines for Adjudicating Applications for Marriage Dispensation, that the judge must hear the two prospective brides and grooms including the parents of the prospective spouses. Before the judge examines the subject matter of the case, the judge must first provide advice so that the two prospective brides who are requested for a marriage dispensation understand the risks of early/underage marriage, including; (a) possible cessation of education; (b) non-fulfillment of the 12-year compulsory education which is the minimum education standard set by the government; (c) the reproductive organs are not yet ready; economic, social and psychological impacts; potential disputes and Domestic Violence (KDRT).

The efforts of the Religious Courts to find facts in the examination of children for whom the Marriage Dispensation is requested is by using 
communicative language and normal appearance or not using court attributes to create a conducive atmosphere so that children are not awkward/uneasy and can easily and plainly/honestly convey the actual facts.This is based on Article 11 paragraphs 1 and 2 of the Regulation of the Supreme Court of the Republic of Indonesia Number 5 of 2019 concerning Guidelines for Adjudicating Applications for Marriage Dispensation which reads; (a) Judges in the trial use language and methods that are easy for children to understand; (b) Judges and Substitute Registrars in examining children do not use trial attributes. ${ }^{15}$

4) Letter of Evidence

Hierarchy (sequence/level) of civil proceedings at the Religious Court session after the advice and cross-check stage of the posita or the arguments/reasons for the application, then the next step is the verification stage. Examination of evidence begins with examination of letter of evidence. ${ }^{16}$ Letter of evidence in the case of a marriage dispensation application based on Article 5 of PERMA Number 5 of 2019 includes, among others; (a) Copy of Identity Card (KTP) of both Parents/Guardians; Copy of Family Card (KK); (b) Copy of Child's Identity Card and/or Child's Birth Certificate (AktaKelahiran); (c) Copy of Identity Card or Child Identity Card and/or Birth Certificate of the Prospective husband/wife; and; (d) Copy of Child's Last Education Diploma (Ijazah) and/or Certificate of Still in Schooling from Child's School. ${ }^{17}$

In addition to the letter of evidence mentioned above, there is still additional evidence required by Watampone Religious Court including: First, the original letter of refusal of marriage from the sub-district religious affairs office. Rejection because they have not reached the age of marriage, the applicant who has been rejected is an interested party in the case of the application (Persona Standi in Yudiclo) so that the applicant has the right (Legal Standing) to submit the application. The refusal of marriage registration by the District Office of Religious Affairs to people who have not reached the age of 19 years based on Law no. 16 of 2019 concerning Amendments to Law No. 1 of 1974 concerning Marriage is the embodiment of Article 7 paragraphs 1 and 2 of the Marriage Law.Based on the same regulation, it is the Religious Courts who have the authority to issue

\footnotetext{
${ }^{15}$ Republic of Indonesia, Supreme Court Regulation Number 5 of 2019 concerning Guidelines for Adjudicating Applications for Marriage Dispensation, Chapter IV Part Two, Article 11.

${ }^{16}$ Jamaluddin, T. "Mobile Marriage Itsbat Session: Its Importance for The Unregistered Marriages." Al-Bayyinah 4.1 (2020): p. 9.

${ }^{17}$ Republic of Indonesia, Supreme Court Regulation Number 5 of 2019 concerning Guidelines for Adjudicating Applications for Marriage Dispensation, Chapter III Part Two, Article 5 paragraph 1 letter b to $f$.
} 
legality/marriage permits. Therefore, all applications for marriage under the age of 19 are rejected by all KUA throughout Indonesia.

Second, Certificate of Unsettling from the Village Official for those who have a reason to be disturbing, sometimes there are also those who do not have it, then the witness evidence that is very decisive is granted or rejected the application for Marriage Dispensation. ${ }^{18}$ The Certificate ofUnsettlingonly serves as evidence of instructions, confirmation, and complement that will suffice for the evidence submitted and at the same time can further convince the judge.

An application for a Marriage Dispensation whose reason or core posita is disturbing means that the application for a Marriage Dispensation, its existence is unsettling in the village community. In procedural law, to prove the truth of the legal event, the applicant is required to take a Certificate of Unsettling from the local Village Official to serve as evidence.This is based on requirements published by Watampone Religious Court. Based on a statement from the Deputy Chairperson of Watampone Religious Court, that the disturbing statement was the own initiative of the Chairperson of Watampone Religious Court and was valid only at Watampone Religious Court. ${ }^{19}$

Third,Certificate of Pregnancy from a Medical Personnel (doctor) for those who reason to be pregnant. ${ }^{20}$ It was determined by the Chairperson of Watampone Religious Court that a certificate of pregnancy was also required for applicants who argued that they were pregnant. Certificate of Pregnancy, which explains that the application for Marriage Dispensation is proven to be healthy and is currently pregnant.As a follow-up to a quo meeting, the Chairperson of Watampone Religious Court instructed the Post and Legal Aid (Posbakum) of Watampone Religious Court to only serve requests for Marriage Dispensation that received a recommendation from the P2TP2A office in casu reasoning that she was pregnant, meaning refusing other than those with reasons of being pregnant. After the implementation of a quo chairman's instructions, the number of incoming cases drastically decreased. ${ }^{21}$

The a quo policy of the Chairperson of Watampone Religious Court caused controversy among judges, some accepted, and some rejected. Responding to the problems that occurred, the Deputy Chairperson of Watampone Religious Court,

${ }^{18}$ Muh. Kasyim, Watampone Religious Court Judge, Interview on Jalan Laksamana Yos Sudarso, 22 August 2019.

${ }^{19}$ Saifuddin, Deputy Chairperson of Watampone Religious Court, Online Interview Via Whatsapp, 18 June 2020.

${ }^{20}$ Implementation of Article 15 letter d of Supreme Court Regulation Number 5 of 2019 concerning Guidelines for Adjudicating Applications for Marriage Dispensation.

${ }^{21}$ Saifuddin, Deputy Chairperson of Watampone Religious Court, Online Interview Via Whatsapp, 18 June 2020. 
Saifuddin provided a solution for justice seekers to apply online (e-court/elitigation) with the aim of eliminating the impression that "active justice" violates the principle of "passive justice"as in Article 56 paragraph (1) of Law no. 7 of 1989 concerning the Religious Courts jo. Article 10 paragraph (1) of Law no. 48 of 2009 concerning Judicial Power, that "Courts are prohibited from refusing to examine, try and decide on a case submitted on the pretext that the law does not exist or is unclear, but is obliged to examine and try it".

One of the justice seekers asked the researcher for consideration before submitting the application for Dispensation to Marriage to Watampone Religious Court, after the researcher confirmed it to the Registrar of the Application.The Registrar advised not to submit the application even through e-court, because all incoming cases must be the chairman who appoints the panel and judges. If there is a marriage dispensation application that does not get a recommendation from the P2TP2A office, the chairman immediately takes over, and it will definitely be rejected. Furthermore, the Registrar and a judge recommended that they are unregisteredly marriage (siri), later after they are old enough, the marriage certificate was requested. ${ }^{22}$

\section{5) Witness Evidence}

At least 2 (two) witnesses are the main keys or determinants of the granting of a marriage dispensation case. However, the potential for lying witnesses in the trial is very possible and besides that no one can intervene (witnesses must be free and must not be influenced by any party).

However, through the experience and creativity of a judge, sometimes through witnesses, it is found that there is a truth that contradicts the posita. Two judges of Watampone Religious Court, namely Muh. Kasyim and Husniwati, both have experience in revealing facts through creativity and by interrogating witnesses when indications of lies are detected, so that the real truth appears through honest confessions (without influence/pressure) from witnesses. ${ }^{23}$

Despite various attempts by judges to direct witnesses to tell the truth and not to lie, there are still witnesses who have succeeded in telling lies so that a case is granted. ${ }^{24}$ According to Drs. H. Ramly Kamil, M.H., one of the judges of

\footnotetext{
${ }^{22}$ Asir Pasimbong Alo, Registrar of Applications at Watampone Religious Court, Interview via Phone, 18 July 2020.

${ }^{23}$ Husniwati and Muh. Kasyim, Watampone Religious Court Judges, Interview on Jalan Laksamana Yos Sudarso, 23 July 2019.

${ }^{24}$ Statement of a student who admitted that his cousin was married off by his parents and grandmother by telling his witness to lie that the child for whom the Marriage Dispensation was requested is already pregnant, who is not actually pregnant, having address at Bajoe, Districtof East Tanete Riattang, Interview at Jalan Dr. Wahidin Sudirohusodo Watampone, 15 September 2018.
} 
Watampone Religious Court, that the judge only heard and saw the facts that emerged in the trial. As for someone who manages to lie, it is beyond the ability and capacity of the judge, what is clear is that the judge always tries to apply the law as optimally as possible. ${ }^{25}$

6) Recommendations from the Integrated Service Center for Women and Children Protection (P2TP2A)

A letter of recommendation from the Integrated Service Center for Women and Children Protection (P2TP2A) is also a required evidence in Watampone Religious Court. Based on data from the P2TP2A Office, if a child is applied for a Marriage Dispensation for unsettling reasons, it is generally rejected.In general, underage children who are recommended to be allowed to marry are only children who are requested for a Marriage Dispensation on the grounds of being pregnant. However, the reason for being pregnant tends to be used by the community as an excuse to apply for a marriage dispensation to the court. ${ }^{26}$

In line with this, as stated by the Head of P2TP2A, Agung Rahmadi, S.Sos., MM., that people who apply for a marriage dispensation for minors are not given permission if they are not in a state of urgency, are pregnant and so on. According to him, since the replacement of the chairman of Watampone Religious Court, the P2TP2A recommendation letter has become the main consideration in giving a decision/determination on the case for the application for a marriage dispensation.Agung continued that since early January 2020, the recommendation for dispensation from marriage by $\mathrm{P} 2 \mathrm{TP} 2 \mathrm{~A}$ began to be tightened, where the applicant's application file that did not receive a recommendation from P2TP2A would be rejected or could not proceed to the trial stage because according to the chairman of Watampone Religious Court if it was already at the trial stage, then judges can no longer be intervened.

The provision of a marriage dispensation recommendation by the Integrated Service Center for the Protection of Women and Children (P2TP2A) in accordance with the Regulation of the Supreme Court of the Republic of Indonesia Number 5 of 2019 concerning Guidelines for Proceeding the Application for Marriage Dispensation.If there is a refusal by Watampone Religious Court and or is not continued to the trial stage because the applicant does not have a recommendation, then the community/applicant returns to P2TP2A asking for a recommendation to be given. According to AgusRahmadi, before issuing a

\footnotetext{
${ }^{25}$ Husniwati Ramly Kamil, M.H, Watampone Religious Court Judge, Interview on Jalan Laksamana Yos Sudarso, 15 October 2019.

${ }^{26}$ Bagya Agung Prabowo. "Pertimbangan Hakim dalam Penetapan Dispensasi Perkawinan Dini Akibat Hamil di Luar Nikah pada Pengadilan Agama Bantul. "Jurnal Hukum Ius Quialustum 20.2 (2013): p. 305.
} 
recommendation, the community are first given education through counseling guidance, to the applicant and his parents, although in the end P2TP2A still refuses and does not give permission, parents who marry off their underage children on the grounds that they are no longer able to care for their children due to economic problems and promiscuity. The impact of underage marriage is the high number of divorces, domestic violence and neglection. ${ }^{27}$

Watampone Religious Court was visited by a team from Unicef, P2TP2A, NGOs, Gender activists and several Village Officials who questioned the existence of 107 requests for recommendations for marriage of underage children which were rejected by P2TP2A but were granted by Watampone Religious Court, meaning that they were given permission to marry under 19-year-old children (Article 7 paragraph 1 of Law Number 16 of 2019).Watampone Religious Court granted 100 cases of Marriage Dispensation out of 107 which were rejected by P2TP2A of Bone Regency because based on the analysis and consideration of the judge on the 100 cases the application for Marriage Dispensation had met the juridical requirements (material requirements and formal requirements) or according to procedural law and material law so that thosewere granted.In other words, the evidence submitted by the applicant has reached the minimum limit of evidence that convinces the judge. According to the statements of several judges, that in general the application for Marriage Dispensation is granted or rejected, it is largely determined by the witnesses and the truth presented by the parties concerned (both bride and groom's parents) through the analysis and conclusions of the judge. ${ }^{28}$

Watampone Religious Court rejected 7 other cases of application for Marriage Dispensation because the judge heard direct explanations from the two prospective husbands/wives, both together and separately clarified in order to find the actual facts.It turned out that the 7 cases that were rejected showed indications of coercion, because it was proven that after the candidates for the dispensation were asked separately, they admitted that they did not want or were not ready to have an early marriage. ${ }^{29}$

7) The relationship between the two (for which the Marriage Dispensation was requested and the prospective husband/wife) is already very intimate and difficult to separate.

${ }^{27}$ Agung Rahmadi, Head of the Integrated Service Center for the Protection of Women and Children (P2TP2A) of Bone Regency, Interview on Jalan Andi Mappayukki Watampone, 15 April 2020.

${ }^{28}$ Muh. Kasyim, Nurmiati, Husniwatiand Ramly Kamil, Watampone Religious Court Judges, Interview on Jalan LaksamanaYos Sudarso, 23-25 July 2019.

${ }^{29}$ Saifuddin, Deputy Chairperson of Watampone Religious Court, Online Interview Via Whatsapp, 18 June 2020. 
Submission of an Application for Marriage Dispensation at Watampone Religious Court on the grounds (posita) that it is unsettling to the community, is required to complete the application with a Certificate of Unsettling from the local Village Official. ${ }^{30}$ The submission of the application is carried out after the two candidates are willing and in love with each other and the respective families of the two prospective husbands/wives agree and agree to carry out the marriage, so that if the marriage is postponed it is feared that it will cause unwanted things. Besides the Certificate of Unsettling which serves as evidence of social Unsettling, witnesses and the recognition of related parties are still needed as the main evidence that strengthens other evidence which results in the judge's belief being stronger in the truth of the legal event.

8) The principles of marriage according to Islamic marriage law and the minimum age limit for marriage (PERMA Number 5 of 2019)

Judges in examining, adjudicating and making decision for cases of marriage dispensation applications still refer to the principles of marriage according to Islamic marriage law, namely the fulfillment of the pillars and conditions of marriage.In the event that the judge grants the application for a Marriage Dispensation which means giving permission to a child to marry, it indicates that the child has fulfilled the pillars and requirements of marriage, while the condition is not yet old enough, with considerations of benefit.

Based on the preamble of PERMA Number 5 of 2019 concerning Guidelines for Adjudicating Applications for Marriage Dispensation, namely that Indonesia is a party to the Convention on the Rights of the Child confirms all actions regarding children carried out by all relevant institutions including the Religious Courts, implemented in the best interests of the child. This shows that the actions or decisions / decisions of the Religious Courts which grant or give marriage permits to early childhood are already in the right corridor and regulation, namely through careful legal analysis and considerations (istinbath and legal discovery methods) by always prioritizing the best interest for the child. ${ }^{31}$

9) The principle of "(Preventing harm takes precedence over profit/benefit)

After going through the constituency/analysis of the judge adjudicating the case of the application for a Marriage Dispensation, it is related to the preamble of PERMA Number 5 of 2019 which states that the Marriage Dispensation is carried

${ }^{30}$ Asir Pasimbong Alo, Registrar of Applications at Watampone Religious Court, Interview on Jalan LaksamanaYos Sudarso, 1 July 2020.

${ }^{31}$ Preambuleof Supreme Court Regulation Number 5 of 2019 concerning Guidelines for Adjudicating Applications for Marriage Dispensation. 
out in the best interests of the child, this is in line with the rules of fiqh, namely" درء المفاسد مقدم على جلب المصالح "means that preventing harm takes precedence over benefiting. Hence related to this, in principle the harm must be eliminated. $^{32}$

Preventing damage means that the product of the Court that grants the application for Marriage Dispensation is a form of effort to refuse or eliminate disgrace, unclear lineage for the child being conceived (for those who are pregnant), noise and anxiety (for those who are anxious), the mental condition of the child and his parents ( the two big families) are upset,then by holding the marriage after obtaining permission from the court, it is hoped that all forms of evil and losses mentioned above will disappear so as to create a conducive atmosphere among the two families for whom the Marriage Dispensation is requested, and society in general.

\section{The Triggers of Application for Marriage Dispensation and Solutions for Underage Marriage}

The number of requests for Marriage Dispensation is triggered by several factors, First, cultural factors, several sources stating that often parents are willing to marry off their children at an early age because they want to have grandchildren soon, some even lie, and tell witnesses to also lie during the trial at Watampone Religious Court, that the child who wants to marry is already pregnant (actually the child is not pregnant), the reason for the lie is that the goal is to be quickly granted and immediately married. ${ }^{33}$ Second, the economic factor, because parents are less able and can no longer support their children. Third, promiscuity, which causes a lot of unrest in the community and what is even more fatal is getting pregnant out of wedlock, and to avoid further harm and slander in the future, an application for Marriage Dispensation is filed. ${ }^{34}$

\section{1) Promiscuity}

Young people's relationships in the form of courtship and already in an intimate state, often have fatal consequences. The occurrence of pregnancy is the aftermath of courtship that is not controlled by parents. As a result of the promiscuity, there was a courtship relationship and then continued to intimate relationship.This intimate relationship has given rise to conditions that are not

\footnotetext{
${ }^{32}$ Ro' is Alfauzi, "The Dynamics of Qawaid F iqhiyyah: The Construction and Application in Islamic Law." Al-Bayyinah 4.2 (2020): p. 229.

${ }^{33}$ Fitrah Handayani, A student of IAIN Bone, Interview on Jalan Dr. Wahidin Sudirohusodo, 13 August 2019.

${ }^{34}$ Nurmiati, Watampone Religious Court Judge, Interview on Jalan Laksamana Yos Sudarso, 23 July 2019.
} 
conducive or are termed "disturbing" in society. Mubasyaroh used the term "marriage by accident". The occurrence of pregnancy out of wedlock, because the children have a relationship that violates the norms, forcing them to have an early marriage, in order to clarify the status of the child being conceived. Pregnancy out of wedlock and parents' fear of getting pregnant out of wedlock encourage their children to marry at an early age. ${ }^{35}$ The results showed that promiscuity and pregnancy were the reasons for applying for a marriage dispensation.
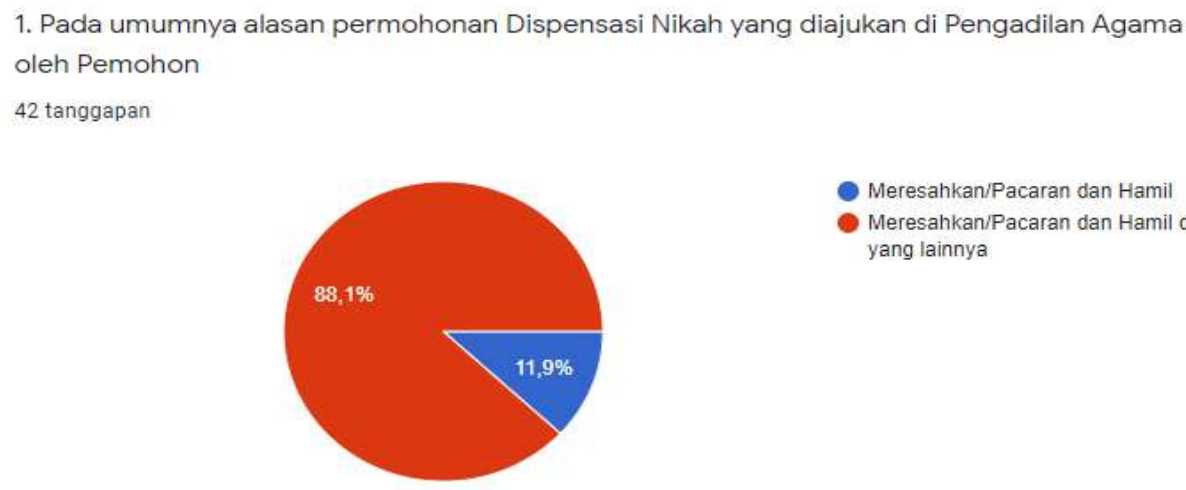

- Meresahkan/Pacaran dan Hamil

Based on the results of the study, out of 42 respondents, $88.1 \%$ of respondents stated that the reason for the application for Marriage Dispensation filed in the Religious Courts was because the courtship of the two prospective husbands/wives had been troubling, a controlled courtship resulted in pregnancy. The remaining $11.9 \%$ stated that apart from disturbing reasons in the form of a very intimate relationship (dating), and being pregnant, there were others such as dropping out of school and even working.According to the Deputy Chairperson of Watampone Religious Court, apart from being pregnant and disturbing, it is also possible for someone who is 18 years old to be given a marriage dispensation on the grounds that they are physically and psychologically capable and there is no longer any opportunity to continue their education. ${ }^{36}$

\section{2) Economic Factor}

The economy is one of the factors that lead to dropouts, so that children who drop out of school end up getting married. This means that they do not continue their education so that they only get married when someone proposes to them. The occurrence of child marriage is caused by poverty, the results of research

\footnotetext{
${ }^{35}$ Mubasyaroh, Analisis Faktor Penyebab Pernikahan Dini dan Dampaknyabagi Pelakunya, Jurnal Pemikiran dan Penelitian Sosial Keagamaan, YUDISIA, Vol. 7 No. 2, December 2016, p. 401.

${ }^{36}$ Saifuddin, Deputy Chairperson of Watampone Religious Court, Online Interview Via Whatsapp, 18 June 2020.
} 
An Analysis of Judges' Considerations in Making Decision About....

Jamaluddin T \& Yusuf Djabbar

DOI: $10.35673 /$ al-bayyinah.v4i2.981

in 27 sub-districts in Bone Regency show that the causes of child marriage under the age of 19 include: (a) The influence of social media (mobile phone, internet, etc.); (b) Low access to education; (c) Quality of reproductive health services and education; (d) Economy/poverty; (e) Family, such as pressure from parents (old age) because they want to see their children get married, and want to pet their grandchildren. Of the 5 items, there are $97.5 \%$ who include point 4 (economy/poverty) in addition to other influences as the cause of the large number of underage marriages.

\footnotetext{
5. Yang mana di bawah ini penyebab utama pernikahan anak di wilayah bapak : 1.Pergaulan bebas dan pengaruh lingkungan; 2. Pengaruh Medsos (HP, internet dII); 3. Rendahnya akses pendidikan: 4. Kualitas layanan dan pendidikan kesehatan reproduksi 5.Ekonomi/Kemiskinan 6.Keluarga, seperti desakan Orangtua (usia senja) karena ingin melihat anaknya berumah tangga dan ingin menimang cucu.Yang mana yang dominan?

41 tanggapan
}

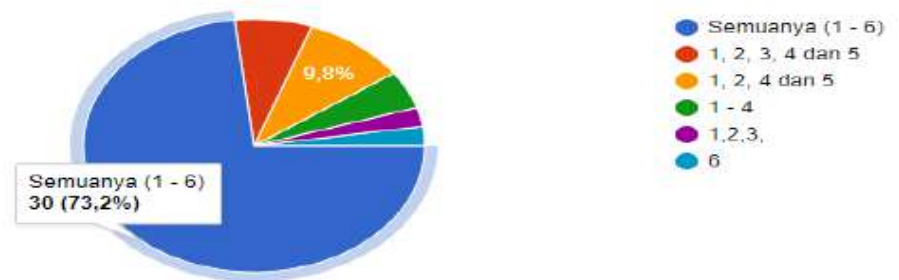

Therefore, a girl who quits school, once someone proposes to her, is easily accepted because there is no longer anything preventing her from getting married (because she does not go to school). It is also understood from the context of 'mappattuntu', it shows that the relationship between the economy and continuing education for the Bugis community, especially in Bone Regency is very strong so that not a few people are found to have underage marriages due to dropping out of school. ${ }^{37}$

3) Culture

The phenomenon of underage marriage has occurred in the community since ancient times so that it has become a habit or culture that is often seen as permissive from the community. In addition, it also contributes to the community's belief that children who marry underage according to laws and regulations do not have a significant negative impact on children.According to them, old people in the past generally married underage, but their descendants were fine, and many were even successful in the economic field.

The thing that affects the most is the conception of siri that is inherent in the people of Bone Regency. Including not getting married is understood as a form of shame (masiri), so it is not surprising that if there is an application, the parents

${ }^{37}$ Usman, Community Figure, Interview on Jalan Dr. Wahidin Sudirohusodo Watampone, 15 July 2020. 
will accept it because they are afraid of not getting married.In fact, it also happens to those who continue their education, sometimes they have to go to school/college as well as get married because they do not know that. Thus, it is not surprising that the influence of community culture in understanding the strong view of life in the community is one of the factors in the occurrence of underage marriage.

The solutions for underage marriage include:

1) Pre-Marriage Education and Welfare Improvement

Since 2017, the Ministry of Religion of Bone Regency cq Islamic Community Guidance (Bimas Islam) has implemented a program of pre-marital education activities. This pre-wedding education activity is carried out every year in several strategic and representative places, the participants are high school students (SLTA), both Madrasah Aliah and and vocational high schools. As for 2020, there has been a budget, but due to Covid-19, the implementation has been postponed. ${ }^{38}$ Based on questionnaires distributed to 27 sub-districts throughout Bone Regency which questioned the solution to early childhood marriage, from 42 respondents, 26 (61.9\%) respondents stated that "education and improving community welfare" was the best solution.

7. Solusi Pernikahan Anak Usia Dini

42 tanggapan
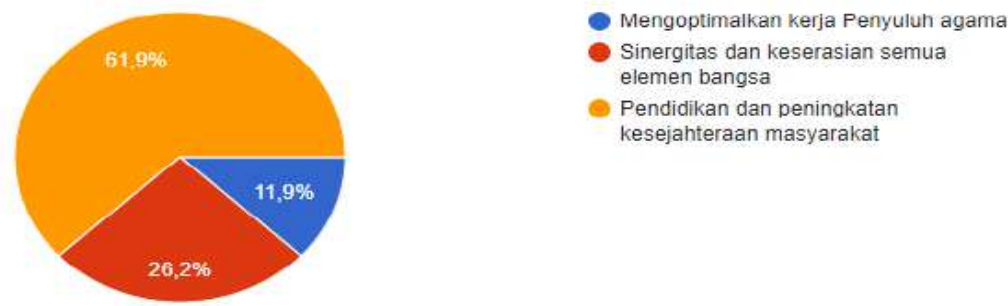

The result of the questionnaire above indicates that there is a significant influence on a person's education and welfare (economy), which can affect children's continuing education. The consequences of continuing children's education will block the way for early marriage. On the other hand, if a child has dropped out of school, especially a girl, then there is no reason not to marry her if someone proposes to her.As for if a family cannot afford it, then it is very difficult for them to continue their children's education, because education is expensive. The meaning of expensive can be in the form of costs that will be incurred, and children who go to the school cannot take part in helping parents support the family economy.Looking at the phenomena mentioned above, it shows that the

${ }^{38}$ Sawiah, Compiler and Operator of Islamic Community Guidance at the Ministry of Religious Affairs at Bone Regency, Interview on Dr. Wahidin Sudirohusodo Watampone, 18 July 2020. 
welfare factor (low economy) is the main factor in the birth of dropouts and the massive number of underage marriages.

2) The Role of the District Office of Religious Affairs (KUA)

The role of the District Office of Religious Affairs in reducing the rate of early marriage by providing guidance and counseling, either directly, through village religious leaders (imam), or religious counselors.Based on the results of the questionnaire, it was shown that KUA's efforts in educating and understanding the public about the importance of being of sufficient age at marriage and the dangers of underage marriage are as follows:

4. Upaya KUA dalam mengedukasi dan memahamkan masyarakat akan pentingya cukup umur pernikahan dan bahayanya nikah di bawah umur:

42 tanggapan

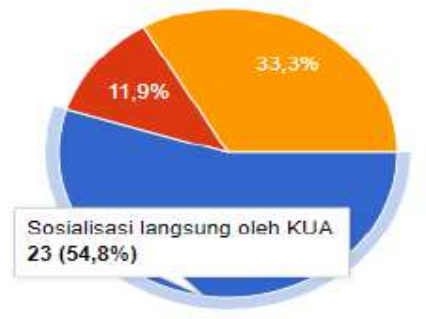
Sosialisasi langsung oleh KUA
Sosialisasi melalui imam
Penyuluhan melalui para penyuluh, baik
Penyuluh PNS maupun non PNS

The three forms of activity mentioned above show that there is a serious effort made by the District KUA in educating the community so that the community understands the importance of being of sufficient age for marriage and the dangers of underage marriage.However, based on statements from several parties which are supported by some data, it shows that the government's efforts through the Ministry of Religious Affairs through the Islamic Community Guidance have carried out counseling and pre-marital education in Watampone city area, and were followed up by the District KUA to carry out counseling and pre-marital education in their respective sub-districts, but the results have not shown any significant changes, which are marked by the prevalence of early marriage and the application for Marriage Dispensation.According to the author, this is caused by promiscuity factors (intimate relationships and pregnancy), economics, culture, and education exacerbated by the permissive attitude of society in general, very few components of society are concerned about this problem.

\section{Conclusion}

The judges in examining and adjudicating Marriage Dispensation cases are carried out based on the Regulation of the Supreme Court of the Republic of 
Indonesia Number 5 of 2019 concerning Guidelines for Adjudicating Applications for Marriage Dispensation. The judge's consideration in making decision of the application for Marriage Dispensation begins with advice or efforts to raise awareness of the risks of early marriage, such as physical, psychological, reproductive organs, social, economic readiness and the potential for disputes and domestic violence.In exploring the truth value of posita, judges dress in plain clothes, are friendly and embracing, then clarify separately (individually) to be more open, honest, free and not feel pressured. The judge conducted a constituency (analysis) of the positive relationship and evidence, such as intimacy of the relationship, indications of pregnancy, the willingness/readiness of the two candidates and considering the benefits of the two candidates. The factors triggering underage marriage are due to promiscuity with dating culture, poverty, culture and public understanding of the validity of underage marriage.Some of the solutions offered in handling child marriage are by providing pre-marital education, improving community welfare and maximizing the role of religious instructors in each Office of Religious Affairs (KUA).

\section{References}

Alfauzi, Ro'is “The Dynamics of Qawaid Fiqhiyyah: The Construction and Application in Islamic Law.” Al-Bayyinah 4.2 (2020): 225-242

Hamzah, Hamzah. "PERANAN PERADILAN AGAMA DALAM PERTUMBUHAN DAN DINAMIKA HUKUM KEWARISAN DI INDONESIA." ALSYAKHSHIYYAH Jurnal Hukum Keluarga Islam dan Kemanusiaan 2.2 (2020): 122-139.

Ilma, Mughniatul. "Regulasi Dispensasi dalam Penguatan Aturan Batas Usia Kawin bagi Anak Pasca Lahirnya UU No. 16 Tahun 2019." AL-MANHAJ: Jurnal Hukum dan Pranata Sosial Islam 2.2 (2020): 133-166.

Jamaluddin, T. "MOBILE MARRIAGE ITSBAT SESSION: ITS IMPORTANCE FOR THE UNREGISTERED MARRIAGES." Al-Bayyinah 4.1 (2020): 119.

Mubasyaroh. Analisis Faktor Penyebab Pernikahan Dini dan Dampaknya bagi Pelakunya, Jurnal Pemikiran dan Penelitian Sosial Keagamaan, YUDISIA, Vol. 7 No. 2, December 2016.

Nata, Abuddin. Metodologi Studi Islam. Jakarta: Raja Grafindo Persada,1998.

Prabowo, Bagya Agung. "Pertimbangan Hakim dalam Penetapan Dispensasi Perkawinan Dini Akibat Hamil di Luar Nikah pada Pengadilan Agama Bantul." Jurnal Hukum Ius Quia Iustum 20.2 (2013): 300-317. 
An Analysis of Judges' Considerations in Making Decision About....

Jamaluddin T \& Yusuf Djabbar

DOI: 10.35673 /al-bayyinah.v4i2.981

Rusli, Rusli, Nur Mohamad Kasim, and Duke Arie Widagdo. "Law Enforcement on the Inheritance of Siri Married in the Judicial Verdict." Al-Bayyinah 4.2 (2020): 133-150.

Republika, BKKBN: 375 Remaja Menikah Dini Setiap Harinya, Lihat https://nasional.republika.co.id/berita/nasional/umum/ps4am9459/bkk bn, Accessed onWednesday, 7 August 2019.

Soekanto, Soerjono. Pengantar Penelitian Hukum. Third Print, Jakarta: UI Press, 1986.

Penelitian Hukum Normatif: Suatu Tinjauan Singkat. Jakarta: Raja Grafindo, 2001.

Republic of Indonesia, Supreme Court Regulation Number 5 of 2019 concerning Guidelines for Adjudicating Applications for Marriage Dispensation.

Soekanto, Soerjono and Sri Mamuji. Penelitian HukumNormatif. First Print, Jakarta : PT Raja Grafindo Persada, 1990.

Usman, Rachmadi. Aspek-Aspek Hukum Perorangan dan Keluarga di Indonesia. Jakarta: Sinar Grafika, 2006. 